\author{
Ognjen Gajic \\ Kaiser G. Lim \\ Rolf D. Hubmayr
}

\section{In Memoriam: Bekele Afessa, M.D.}

Received: 28 January 2013

Accepted: 29 January 2013

Published online: 16 February 2013

(C) Springer-Verlag Berlin Heidelberg and ESICM 2013

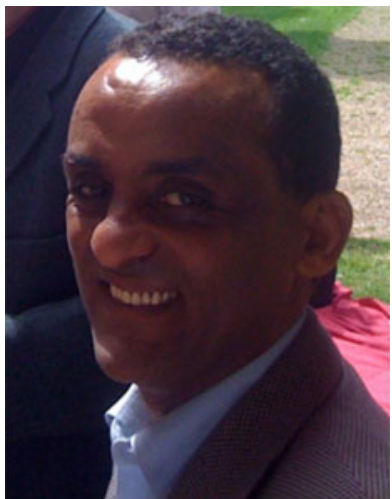

Dr. Bekele Afessa, Professor of Medicine and prominent clinician, educator, and researcher at the Mayo Clinic, passed away Thursday, January 10, 2013, in Rochester, Minnesota. He was 57.

During more than a three-decade career in pulmonary and critical care medicine, Dr. Afessa has authored close to 150 research publications and book chapters. He made special contributions in the fields of sepsis [1-4], ventilator-associated pneumonia [5-7], ICU complications in recipients of bone marrow transplantation [8-13], and critical care outcomes research [14-24].
However, Dr. Afessa was much more than an amazingly talented physician-scientist. He was an early and unusually focused leader in quality improvement and patient safety in the intensive care unit. His research made major contributions to accomplish the goal of improving critical care delivery at the Mayo Clinic and gained him international respect among the critical care community. Dr. Afessa was the first who challenged the idea that critical care delivery at our institution was "perfect". He talked about quality and safety before many of us could spell these words. He was known for his unquestioned honesty and determination, and never backed down if the data showed that change was needed. He was way ahead of his time and of course in hindsight was proven correct. Because he was not a politician he rarely received "official" recognition but he contributed more than anyone to the improvements in critical care delivery in our institution and beyond.

More enduring will be his legacy in educating and training the next generation of intensive care physicians. He shared his knowledge freely with peers, residents, students, nurses, pharmacists, and respiratory therapists. He was elected a teacher-of-theyear every single year since coming to the Mayo Clinic. He was always very kind to his students and juniors, and tough on the bosses. A passionate advocate for improving critical care education and patient care worldwide, he was a true mentor and role model for many.

Dr. Afessa's outstanding professional achievements pale in comparison to his attributes as a human being. He combined toughness of mind and discipline with humility and compassion. He was a uniquely gentle soul. Like a shining lantern, he showed the way and brightened the journey of those who traveled with him. His absence will be felt in the
ICU, the squash court, and in our hearts. Colleagues from all over the world will miss him.

\section{References}

1. Schramm GE, Kashyap R, Mullon JJ, Gajic O, Afessa B (2011) Septic shock: a multidisciplinary response team and weekly feedback to clinicians improve the process of care and mortality. Crit Care Med 39:252-258

2. Afessa B, Greaves WL, Frederick WR (1995) Pneumococcal bacteremia in adults: a 14-year experience in an innercity university hospital. Clin Infect Dis 21:345-351

3. Afessa B, Morales I, Weaver B (2001) Bacteremia in hospitalized patients with human immunodeficiency virus: a prospective, cohort study. BMC Infect Dis 1:13

4. Salman S, Bajwa A, Gajic O, Afessa B (2008) Paroxysmal atrial fibrillation in critically ill patients with sepsis. J Intensive Care Med 23:178-183

5. Kollef MH, Afessa B, Anzueto A Veremakis C, Kerr KM, Margolis BD, Craven DE, Roberts PR, Arroliga AC, Hubmayr RD, Restrepo MI, Auger WR, Schinner R (2008) Silver-coated endotracheal tubes and incidence of ventilator-associated pneumonia: the NASCENT randomized trial. JAMA 300:805-813

6. Afessa B, Hubmayr RD, Vetter EA, Keegan MT, Swanson KL, Baddour LM, Cockerill FR 3rd, Peters SG (2006) Bronchoscopy in ventilator-associated pneumonia: agreement of calibrated loop and serial dilution. Am J Respir Crit Care Med 173:1229-1232

7. Afessa B, Shorr AF, Anzueto AR, Craven DE, Schinner R, Kollef MH (2010) Association between a silvercoated endotracheal tube and reduced mortality in patients with ventilatorassociated pneumonia. Chest 137:1015-1021

8. Afessa B, Azoulay E (2010) Critical care of the hematopoietic stem cell transplant recipient. Crit Care Clin 26:133-150

9. Afessa B, Litzow MR, Tefferi A (2001) Bronchiolitis obliterans and other late onset non-infectious pulmonary complications in hematopoietic stem cell transplantation. Bone Marrow Transplant 28:425-434 
10. Afessa B, Tefferi A, Dunn WF, Litzow MR, Peters SG (2003) Intensive care unit support and Acute Physiology and Chronic Health Evaluation III performance in hematopoietic stem cell transplant recipients. Crit Care Med 31:1715-1721

11. Afessa B, Tefferi A, Hoagland HC, Letendre L, Peters SG (1992) Outcome of recipients of bone marrow transplants who require intensive-care unit support. Mayo Clin Proc 67:117-122

12. Afessa B, Tefferi A, Litzow MR, Peters SG (2002) Outcome of diffuse alveolar hemorrhage in hematopoietic stem cell transplant recipients. Am J Respir Crit Care Med 166:1364-1368

13. Sharma S, Nadrous HF, Peters SG, Tefferi A, Litzow MR, Aubry MC, Afessa B (2005) Pulmonary complications in adult blood and marrow transplant recipients: autopsy findings. Chest 128:1385-1392

14. Afessa B, Gajic O, Keegan MT, Seferian EG, Hubmayr RD, Peters SG (2007) Impact of introducing multiple evidence-based clinical practice protocols in a medical intensive care unit: a retrospective cohort study. BMC Emerg Med 7:10

15. Afessa B, Gajic O, Morales IJ, Keegan MT, Peters SG, Hubmayr RD (2009) Association between ICU admission during morning rounds and mortality. Chest 136:1489-1495
16. Afessa B, Keegan MT, Gajic O, Hubmayr RD, Peters SG (2005) The influence of missing components of the Acute Physiology Score of APACHE III on the measurement of ICU performance. Intensive Care Med 31:1537-1543

17. Afessa B, Keegan MT, Hubmayr RD, Naessens JM, Gajic O, Long KH, Peters SG (2005) Evaluating the performance of an institution using an intensive care unit benchmark. Mayo Clin Proc 80:174-180

18. Afessa B, Keegan MT, Mohammad Z, Finkielman JD, Peters SG (2004) Identifying potentially ineffective care in the sickest critically ill patients on the third ICU day. Chest 126:1905-1909

19. Afessa B, Morales IJ, Scanlon PD, Peters SG (2002) Prognostic factors, clinical course, and hospital outcome of patients with chronic obstructive pulmonary disease admitted to an intensive care unit for acute respiratory failure. Crit Care Med 30:1610-1615

20. Ensminger SA, Morales IJ, Peters SG, Keegan MT, Finkielman JD, Lymp JF, Afessa B (2004) The hospital mortality of patients admitted to the ICU on weekends. Chest 126:1292-1298

21. Finkielman JD, Morales IJ, Peters SG, Keegan MT, Ensminger SA, Lymp JF, Afessa B (2004) Mortality rate and length of stay of patients admitted to the intensive care unit in July. Crit Care Med 32:1161-1165
22. Hanane T, Keegan MT, Seferian EG, Gajic O, Afessa B (2008) The association between nighttime transfer from the intensive care unit and patient outcome. Crit Care Med 36:2232-2237

23. Keegan MT, Gajic O, Afessa B (2012) Comparison of APACHE III and IV, SAPS 3 and MPMOIII, and influence of resuscitation status on model performance. Chest 142:851-858

24. Morales IJ, Peters SG, Afessa B (2003) Hospital mortality rate and length of stay in patients admitted at night to the intensive care unit. Crit Care Med 31:858-863

\section{O. Gajic (ه)}

Mayo Clinic, 200 First Street SW, Rochester, MN 55905, USA

e-mail: gajic.ognjen@mayo.edu

Tel.: +1-507-2556149

Fax: +1-507-2554267

O. Gajic · K. G. Lim - R. D. Hubmayr Pulmonary and Critical Care Medicine, Mayo Clinic, Rochester, MN, USA 